\title{
HOW THE GOTHIC REARED ITS HEAD IN DUTCH LITERATURE
}

Agnes Andeweg

Maastricht University

\begin{abstract}
It was not until the twentieth century, and especially the 1980s, that Dutch Gothic fiction began to flourish. This article gives an overview of the history of the Gothic in Dutch literature, and discusses the explanations given for the absence of a Dutch Gothic tradition. It then examines six Gothic novels from the 1980s in more depth to determine what kind of "cultural work" the Gothic does in late-twentieth century Dutch novels. In those novels, the Gothic is a way of expressing the ambivalences accompanying new societal relations following the 1960s, when constructs of the self in terms of gender and sexuality were reformulated.
\end{abstract}

Keywords: Gothic novel, Twentieth-century Dutch Literature, Gender and Sexuality.

For a very long time, "Dutch Gothic" was simply an oxymoron. ${ }^{1}$ There is no contemporary Dutch equivalent to The Monk (1796),

\begin{tabular}{|l|l|l|l|l|}
\hline Ilha do Desterro & Florianópolis & $n^{\circ} 62$ & p. 127- 151 & jan/jun 2012 \\
\hline
\end{tabular}


even though its author Matthew Lewis worked on his famous novel in The Hague, where he happened to be stationed as a representative of the English crown. Nor is there a Dutch novel comparable to Dracula (1897), despite the fact that Doctor Van Helsing, captain of the "Crew of Light," is Dutch. Even the clearly Gothic potential of the mythological Flying Dutchman-the skeleton ship sailing the world seas-never became the inspiration for a local version of Dutch Gothic. While the Gothic novel was at its peak in European countries such as Britain, Germany, and France around 1800, and again a century later when Bram Stoker published his novel, only a handful original, Dutch Gothic works were produced. This scarcity is remarkable, even considering how modest in size the Dutch book market was at that time (Kloek \& Mijnhardt 2001). This situation remained unchanged until the second half of the twentieth century, but the Dutch Gothic novel did not truly take flight until the 1980s.

In this article I will give a brief overview of the history of the Gothic in Dutch literature, based on the scarce research that has been done so far, and discuss the explanations given for the absence of a Dutch Gothic tradition. Then I will analyze the features of Dutch Gothic fiction of the 1980s, basing myself on a selection of six novels by well-known Dutch writers, which I believe are representative of the surge in popularity of Dutch Gothic fiction.

Before I begin introducing and contextualising Dutch Gothic, however, I will address the more general and vexing question of what Gothic is, in the process explaining my own theoretical take on this phenomenon. For what is Gothic? This seemingly straightforward question has been answered in many different ways. Nowadays, one would probably mainly associate the term Gothic with blackclad youngsters listening to songs by Siouxsie and the Banshees or watching a TV-series like True Blood. However, Gothic-as a 
subculture, musical style or visual genre-was preceded by the Gothic in literature, architecture, painting and even Gothic-inspired politics. ${ }^{2}$ Gothic, in other words, has proven to be an extremely mobile concept which cannot be pinned down to a single cultural form, period or region. But what is the connection between the Utrecht cathedral, a story by Flannery O'Connor and an absinthe party? What links these diverse manifestations, if anything, other than the label "Gothic" itself?

It is my contention that by conceiving of Gothic as a cultural strategy, it is possible to establish a meaningful connection between these and other Gothic phenomena. Or, to put it differently: I believe that describing Gothic as a genre or a style-listing its elements or features-will inevitably lead to an impasse. Gothic is not just about motifs such as zombies and vampires, although we recognize these supernatural beings as Gothic, and it cannot be restricted to aesthetic categories of horror and the sublime, although these are often present. All that is called Gothic is too diverse to be captured in one list, and so any list will be incomplete or even contain contradictory elements.

What I mean by a cultural strategy is best explained by sketching a brief imagological history of Gothic-an undeniably very rough outline of how the Gothic features in cultural history, starting with the Goths, the infamous Germanic tribes. After their alleged sacking of Rome in 476, they became known as the demolishers of the Roman Empire. The Goths were held responsible for the disappearance of classical Roman civilization, and thus were associated with chaos, barbarism, and the advent of the Dark Ages. At least, this is the account given by the Renaissance scholars and humanists who in the sixteenth century wanted to distinguish themselves from the previous historical period. For example, the Italian scholar Giorgio Vasari (1511-1574) wrote about the architecture of medieval cathedrals and 
drew a (historically incorrect) link with the Gothic tribes, dismissing the medieval building style as monstrous and chaotic (De Beer 1948). Ever since, we have known Gothic cathedrals for their pointed and irregular style which sets them apart from (neo-)classicist regular and harmonious lines.

This kind of oppositional reasoning recurred in many variations. The barbarous, irregular and monstrous Gothic of the past was contrasted with the present, which was inevitably seen as more modern and civilized. A more positive interpretation of the Gothic became possible only in the late eighteenth century, when the Middle Ages were revaluated under the influence of Romanticism. The term Gothic acquired a rebellious ring to it, which in Britain even resulted in a brief political use of the term (Clery \& Miles 2000). This example not only illustrates the mobility of the Gothic from one discourse to another, it also marks the turning point in history when what is labelled Gothic becomes an ideal rather than a past best left behind, or simply a threat. Arguably, this ambivalence still characterizes Gothic popular culture. In a sense, the century-old Cullen vampire clan in Stephenie Meyer's Twilight represents the ideal modern family. Yet, they are also quite scary.

Following Robert Mighall's perspective (1999), which stresses the historical and geographical features of Gothic rather than its sublime and/or psychological effects, I see the Gothic as a cultural strategy used to stage the ambivalences caused by modernization. These ambivalences result from a perceived breach between present and past. In Gothic representations, an opposition between a (modern) present and a traditional (Gothic) past is staged-whether by Italian Renaissance humanists, who called the medieval cathedrals Gothic, or by present-day goths who self-consciously want to distance themselves from modern life. Thus, the dynamic of progression and 
stasis-in other words, of modernization-is crucial to the Gothic. As Mighall writes:

Progress has been the dominant idea in organizing postRenaissance thought in the West. And ideas of progress [...] have provided their antitheses, their own myths of Gothic stagnation and oppression. (286)

Gothic as a cultural strategy stages the tensions and conflicts generated by the often violent and abrupt onset of modernity. Gothic shows how modernity may be uncomfortable, how progress always comes at a cost, or how the repressed past returns with a vengeance. The contrast between a modern present and an archaic past can be, and is, staged time and again, with different accents for different periods and aspects of modernization.

This does not mean that Gothic is a subversive strategy by definition. Though Gothic is a way of staging the conflict between representatives of the present and the past, which side ultimately "wins" is not a foregone conclusion-rather it depends on the interpretations of the reader. Gothic novels by the eighteenth-century writer Ann Radcliffe often confirm rather than undermine existing power relations (Baldick \& Mighall 2000). And how subversive is a Gothic subculture that is more of a commercial product than a counter-cultural movement? Labelling cultural artefacts as subversive suggests a certain achievement, but as Alan Sinfield dryly comments: "mostly the government did not fall, patriarchy did not crumble [...] [so] containment must have occurred" (49). In order to avoid overstating Gothic's impact, I prefer to follow Sinfield's suggestion that we use the term dissident instead. Bearing this 
theoretical perspective on Gothic in mind, let us turn to the history of the concept within the Dutch context.

\section{A short history of Dutch Gothic}

The etymological history of the Dutch word for Gothic (gotisch, gotiek) already testifies to the absence of a literary dimension. Unlike in English, where the term Gothic travelled from the realms of geography and history to architecture, literature, and even politics (Clery \& Miles), gotiek never became a literary genre label. Thanks to the availability of the world's largest historical dictionary, the Woordenboek der Nederlandsche Taal (WNT, Dictionary of the Dutch language, started in 1851 and completed in 1998), it is possible to trace the word's etymological history in detail. According to the WNT, which uses a wealth of historical sources to elucidate the different meanings of entries, the word gotiek has been used since the early seventeenth century to refer only to Germanic tribes and their remnants (e.g. the Bible translation in Gothic), a style of architecture, and the derogatory connotation of the barbarous and medieval. In Dutch, Gothic never acquired meaning in a political or literary context. In the National Library Catalogue, only one collection of stories, from 1815, is known with the term Gothic in the (sub)title. This collection, Kleine Romans en Gothische Vertellingen (Novellas and Gothic Tales), however, is the exception that proves the rule; it is no coincidence that this book is a translation from English.

Among the few examples of original, Dutch Gothic fiction are several popular plays from around 1800 , especially from the (Catholic) south of the Netherlands, which are full of gruesome, spectacular events. After 1820, writers of historical novels like Jacob van Lennep 
(De pleegzoon 1833, (The adoptive son)) and Adriaan van der Hoop Jr. (La Esmeralda 1837, an adaptation of Victor Hugo's Notre Dame de Paris), incorporated Gothic narrative elements into their work. In the course of the nineteenth century, several ghost stories were published (collected by Bervoets 1983 and Van Zonneveld 1983). All in all, there is not much.

Several explanations have been given for the absence of original, Dutch Gothic fiction in the eighteenth and nineteenth centuries. Van Gorp (1999) has suggested that this might be due to the fact that, unlike in Britain, the Middle Ages-Gothic fiction's preferred historical setting - were not the most suitable period for legitimizing nationhood, at least not for the northern Low Countries, and so the (Calvinist) seventeenth century was preferred as historical material instead. Secondly, the organization of Dutch literary life in (noncommercial) societies was not conducive to the development of the Gothic. The literary societies stressed the importance of civilizing the populace through literature and encouraged adaptations of biblical matter, which in turn led to more conservative publishing policies than in countries like Britain. In short, Van Gorp attributes the lack of a Dutch Gothic novel to the combination of a demand for decency and a preference for the seventeenth century as historical material.

Another explanation, suggested by Buikema \& Wesseling (2011), may lie in the different pace and phasing of modernization processes in the Netherlands as compared to Great Britain, for instance. Gothic fiction has been fruitfully read as a cultural strategy for broaching the major tensions and fears that accompany modernization processes. In some respects, the Netherlands modernized much earlier, and in other respects later than surrounding countries, which could explain why Gothic was not terribly popular around the 1800s. 
The explanations for the absence of a Dutch variety of the Gothic novel offered by Van Gorp, and Buikema and Wesseling are not mutually exclusive, and both sound plausible enough. Yet there may be more Dutch Gothic fiction, or more Gothic in Dutch fiction, than traditional genre criticism has given us cause to believe. As Hanou (1999) has observed, the enlightened eighteenth-century writing duo Betje Wolff and Aagje Deken (famous for what is considered the first full-fledged novel in Dutch, Sara Burgerhart (1782)) show a remarkable sensitivity to the Gothic machinery in one of their works (Geschrift eener bejaarde vrouw; Writings of an elderly woman, 1802). And the sentimental epistolary novel Het land, in brieven (The country, in letters, 1788) by Elisabeth Maria Post also employs Gothic imagery such as graveyards. Analyzing these, and possibly more works, from the perspective of Gothic as a cultural strategy could well reveal a more prominent presence of the Gothic in Dutch literary history than previously assumed.

To be sure, Gothic fiction is not completely absent in the Netherlands in the eighteenth and nineteenth centuries. The significance of translations should not be underestimated in a relatively small national book market. The English Gothic novel, the French roman noir, but especially the German Schauerroman made their mark through translations, adaptations, and imitations. Dutch literary critics describe the advent of a Gothic "craze" in 1801 as an approaching thunderstorm, rolling from Germany, to Britain and France, and finally reaching the Netherlands. The Gothic fiction that was translated into Dutch was mostly French and German in origin. This was due to the contemporary Dutch cultural orientation towards France, and to a lesser extent towards Germany. Among the authors translated were French writers such as F. DucrayDuminil, J.J. Regnault Warin, and Denis Diderot (La Religieuse), and 
German writers such as H. Zschokke, Veit Weber, C.A. Vulpius, A. von Kotzebue, C.H. Spiess, C. Naubert, and Friedrich Schiller (Der Geisterseher en Die Räuber). British authors were seldom translated. The only exception was Ann Radcliffe, whose work often appeared in Dutch after having been translated from the French. Most of these translations appeared in the first half of the nineteenth century (Van Gorp 1999).

Dutch Gothic literature gained more momentum in the twentieth century. Beginning with a fine example of an imperial Gothic novel set in the Dutch East Indies, The hidden force (1900) by Louis Couperus exhibits the colonizer's fear that the colonized possess supernatural powers. Ferdinand Bordewijk tried his hand at Gothic in his three volumes of Fantastische Vertellingen (Fantastic Tales, 1919-1924). Seminal post-war authors such as Willem Frederik Hermans and Hella Haasse laid down the foundations of a Dutch variety of Gothic with, respectively, the volume of short stories Paranoia (1953) and the novel De verborgen bron (The Hidden Source, 1950).

This surge of Gothic has been connected to the Netherlands' post-war reconstruction in the second half of the twentieth century, which went hand in hand with a strong ideology of domesticity (Buikema \& Wesseling 2006, 2011). As Buikema \& Wesseling (2011) argue, the "domestic Gothic" (Botting 1996) provided authors such as Willem Frederik Hermans and Hella Haasse with the means to show the downside of the sometimes oppressive cult of the happy home. In the wake of these influential writers, the Gothic finally caught on in twentieth-century Dutch literature, developing into a real trend from the eighties onwards. Haasse even spoke of "a fashionable-Gothic niche in the market" (Haasse, 284). In the 1990s the Gothic also became extremely popular in children's fiction, in particular through Paul van Loon's series about a gruesome school 
trip (De griezelbus) and the even more popular Dolfje Weerwolfe series about a seven-year-old orphan boy who discovers that he is a werewolf. Dolfje Weerwolfje (translated into English as Alfie the Werewolf) has been adapted into a musical and more recently into a feature film (2011).

The growing interest of Dutch literary authors and publishers in Gothic fiction, especially in the 1980s, went beyond the publication of numerous collections of translated popular horror, and of historical Gothic stories (Van Zonneveld 1983, Bervoets 1983). Another sign of the nascent Gothic movement was the publication of two volumes of original, Dutch horror stories by leading contemporary novelists, commissioned by Robert-Henk Zuidinga (1984, 1986). In addition, notable authors such as Gerard Reve (1923-2006), Frans Kellendonk (1951-1990), Thomas Rosenboom (1956), Vonne van der Meer (1952), Manon Uphoff (1962) and Herman Franke (19482010) all wrote novels in the Gothic vein. Renate Dorrestein (1954) deserves special mention; almost all of her works (several of which have been translated into English, see www.renatedorrestein.nl) can be classified as Gothic. This "upward mobility" of Gothic warrants a closer analysis of the meanings of Gothic in recent Dutch literature.

For my dissertation, I analyzed six of these Gothic novels from the 1980s in greater detail (Andeweg 2011, in Dutch), focussing on a specific question: what does Gothic do in late-twentieth century Dutch novels? This is in fact a two-fold question, the first aspect of which asks what the effects are of the Gothic in literary terms. To answer this I analyzed how the Gothic makes its appearance in six Dutch novels published between 1980 and 1995: Frans Kellendonk's Letter en Geest (Letter and Spirit, 1982); Gerard Reve's De vierde man (The Fourth Man, 1981); Thomas Rosenboom's Vriend van verdienste (Friend of Merit, 1985); Renate Dorrestein's Noorderzon 
(Midnight Sun, 1986) and Het perpetuum mobile van de liefde (The Perpetual Motion Machine of Love, 1988) and Vonne van der Meer's Spookliefde (Ghostly Love, 1995). The authors take their inspirationsometimes explicitly-from predecessors who wrote Gothic fiction, such as Henry James, and Charlotte Brontë. By analyzing these novels in detail, I explored the potential of a Gothic frame of interpretation, which is a relatively new approach in Dutch literary criticism (Buikema \& Wesseling 2006). I examined which elements from the eighteenth and nineteenth century Gothic tradition created literary effects in these six novels. Although none of these works are considered classic Gothic or horror novels à la Bram Stoker or Stephen King, they all contain Gothic elements: a locked room in the attic, a ghostly apparition in the library, crows in a graveyard, corrupt monks on a remote island, a metamorphosis into a vampire and so on.

My close readings of these six novels also served to answer the second aspect of my original question: what is the Gothic doing there, at that time and place, or in other words, what kind of cultural work is the Gothic effecting in these novels? I borrow the term cultural work from Jane Tompkins' seminal work Sensational Designs (1985), where it is used to refer to how literary works rework and negotiate socio-cultural tensions. Cultural artefacts such as novels are not just a reflection of the society from which they originate, but are also places where societal norms and values are negotiated, undermined, confirmed or created. In Tompkins' words:

[T]he novel functions both as a means of describing the social world and as a means of changing it. It not only offers an interpretive framework for understanding the culture, and, through the reinforcement of a particular code of values, recommends a strategy for dealing with cultural conflict, but it is 
itself an agent of that strategy, putting into practice the measures it prescribes. (135)

From this New Historicist perspective, Gothic fiction can meaningfully be linked to historical developments and be read as one of the discourses that help shape and negotiate new social relations. Particularly an analysis of the Gothic, which I defined as steeped in the discourse of modernization, is suited to expose possible ambivalences regarding modernization processes. In the remainder of this article, I will discuss how this perspective affects the study of recent Dutch Gothic fiction. The discussions of the individual novels will by necessity be brief, but together they will provide a new perspective on recent Dutch history, especially with regard to women's and sexual emancipation and the issue of secularization.

\section{Dutch Gothic fiction in the 1980s}

The six novels I studied were all published well after the 1960s, a period of modernization which greatly influenced the Netherlands in many ways. As historian James Kennedy has noted, a remarkable aspect of that modernization in the Netherlands was the dominance of a "rhetoric of progression," which caused social changes to happen smoothly and swiftly, more smoothly than in surrounding countries, according to Kennedy (1995). The Netherlands quickly became an international icon of sexual liberation, women's emancipation, individualization, and secularization. One might ask what cultural conflicts the Gothic had to rework in a society that experienced such a smooth transition to emancipation. My analysis of the six novels, however, showed that the Gothic had a role to fulfil. In fact, it is the very dominance of this liberated/emancipated discourse that the authors of 
these six novels question. Before discussing the cultural impact of the Gothic in these novels, I will briefly summarize their plots.

Frans Kellendonk's Letter en Geest (Letter and Ghost, 1982) tells the story of a man who decides he needs to enter public life (at the age of 30) by taking a job in a library. There he meets a ghost and is sexually harassed by his superior. Letter en Geest, subtitled A Ghost Story, represents a friction between old and new articulations of homosexual identity through the Gothic (see also Andeweg 2007). Letter en Geest shows the tensions between private and public life, expressed in the blurring discourses of sexuality and working life. The source of these tensions is what Eve Sedgwick in Between Men (1985) has called male homosexual panic: the fear of being perverted. I feel that it is specifically the modern, i.e. late twentieth-century, form of homosexual identity and the way it is constructed which accounts for the Gothicism in Letter en Geest. Kellendonk rewrites the classic ghost story and critiques the effects of sexual emancipation, two issues which are related in this novel. While the classic ghost story derives its narrative tension from an "existential problem" (does the ghost exist?), the male protagonist in Letter en Geest immediately solves the problem of having seen a ghost in the library by bending the definition of knowledge to his will, thus foregrounding the "problem of knowledge." This is analogous to the effect of the modern coming-out strategy for homosexuals: knowledge (knowing and being known) precedes being (homosexual).

Sexual liberation has undoubtedly brought homosexuals greater freedom to come out of the closet. But Letter en Geest shows a possible drawback to this emancipation. When being (existing as a homosexual) is dependent on knowing, either through making oneself known, or through being recognized (known) by others, sexual identity is no longer a matter of private choice. It is an identity 
that has to be claimed and performed in public. In Letter en Geest, Kellendonk uses Gothic strategies to represent the panic potentially accompanying this requirement to claim a sexual identity. Kellendonk presents a character who struggles with the fact that a sexual identity must be staked out in order to exist in the modern age.

The second case is the comic Gothic De vierde man (The Fourth Man, 1981) by Gerard Reve. Parenthetically, The Fourth Man was successfully adapted for the screen in 1983 by director Paul Verhoeven (known for his films Basic Instinct and Robocop), who gave the World War Two film genre a Gothic twist in his recent movie Black Book (2006). De vierde man is clearly inspired by the Gothic novel, but it gives Gothic conventions a comic twist. Here, the homosexual protagonist Gerard has a one-night stand with a woman, Christine, only to become obsessed with her boyfriend. Gerard's superstition leads him to believe that Christine is evil and guilty of murdering three of her partners, and that he will be the fourth. Reve uses the Gothic as a suitable cultural strategy to represent the fragility of the achievements of the sexual revolution of the late 1960s and 1970s. In this novel Christine's sexual pleasure, i.e. sexual autonomy, is portrayed as Gothic, as a threat to Gerard's dominant masculinity. The protagonist's parodies on heterosexual masculinity can be interpreted not only as parodies on gender (Butler 1990) - the faggot who plays a man, in Gerard's own words-but also as parodies on sexuality: the homosexual who plays the heterosexual. Depending on the reader's perspective, these parodies may be read as a critique or a confirmation of the heterosexual romance plot. The position of the male protagonist is ambivalent. On the one hand, he connects gender and sexuality in a heteronormative way. On the other hand, he undermines the notion of naturalness and authenticity through his successful parody of a heterosexual. 
The subversion of authenticity in De vierde man centres on sexual identity, which is often considered the core of the self (Foucault 1978). In the case of Gerard Reve, it is also the core of his authorship. Peter Brooks' theory of narrativity and sexuality (1992) helps to explain the connection between sexuality and authorship in De vierde man. The novel asks two questions: "what is a man?" and "what is a story?" Both questions are answered through an opposition of heterosexuality and homosexuality. I concluded that heterosexuality and the romantic plot are (still) closely related, although Reve effectively exposes the implied naturalness of the romantic plot.

The third novel, Vriend van verdienste (Friend of Merit, 1985) by Thomas Rosenboom, is set in a seemingly archaic past, on the cusp of the 1960s. The novel reworks the classic motifs of the Gothic mansion with a locked room and a mad woman in the attic. A young petty thief, Theo, locks himself into the attic of a villa. This act sets in motion a series of increasingly gruesome events culminating in murder. The novel's main sources of Gothic tension are class and masculinity. Even the suggestion of possible class mobility is violently suppressed in this novel. Excessive violence is released when Theo literally crosses boundaries by locking himself up in the Gothic mansion of the rich boys he wants to befriend. The rivalry between the four protagonists can be analyzed with the help of Eve Sedgwick's work on homosocial bonds (1985). The boys are engaged in a struggle for male dominance. Both the privileged position of the higher class and the values of the self-employed class-in this case servitude as a matter of honour-are put under pressure. This novel centres on the tensions between dependence and independence, between power and powerlessness. The Gothic stages the blurring of boundaries in terms of purity and the abject. Theo-the least masculine of the boys 
in terms of age and class-becomes abject. Paradoxically, he is able to subvert the social order most effectively in this abject position.

The next two novels are both written by the "queen of Dutch Gothic literature", Renate Dorrestein: Noorderzon (Midnight Sun, 1986) and Het perpetuum mobile van de liefde (The Perpetual Motion Machine of Love, 1988). Noorderzon is the story of Topaas, who fears she possesses the Evil Eye because she has caused a traffic accident. She flees to a remote island populated by freaks and criminals. Despite her good intentions things go from bad to worse on the island. Het perpetuum mobile van de liefde is an autobiographical story about Dorrestein's sister's suicide, an account of the genesis of Noorderzon, and a feminist pamphlet-combined with fantastical narrative elements. Dorrestein's work is usually analyzed in the framework of the lively international debate on female Gothic (Haasse 2000). This frame of reference interprets Gothic first and foremost as a quest for female autonomy. Though the feminist issue of autonomy (from men) definitely plays a role, Nancy Armstrong provides an alternative way of interpreting the Gothic in these two Dorrestein novels as a way of imagining a community (Armstrong 2005). In my analysis, the Gothic in Noorderzon and Perpetuum mobile serves to show the limitations of individual agency rather than female agency specifically.

Noorderzon contrasts an ethical worldview of life lived honestly with metaphysical Evil. This Gothic novel thus shows that moral virtue (Topaas' good intentions) cannot prevent evil from happening. Neither is the (professional) narrative power of the protagonist strong enough to avert evil. Topaas, who is a producer of radio plays, uses her professional voice to report on her increasingly troubling experiences on the island by sending audiotapes home. Ultimately, this leads to ambiguity between professional narration 
and personal report, between reality and fiction. This blurring of borders causes Gothic excess.

Het perpetuum mobile van de liefde contains a case of Gothic monstrosity that turns upon feminism itself: the novel portrays (feminist) sisterhood as monstrous, and artistic failure as liberating. The book explores what happens when the monster exhibits an uncanny similarity between Self and Other, rather than a marked difference. It is sameness rather than difference that is the source of Gothic monstrosity, both in the narrator's ambivalent relation with her dead sister-who casts her vampiric shadow over her work-and with the fictional character Godelieve-her "monster of Frankenstein". Dorrestein explores the feminist notion of sisterhood through the autobiographical narrative about her sister's suicide and the fictional story about Godelieve, thereby showing feminism to be anything but monolithic. Through the Gothic, Dorrestein finds modes to express the unspeakable rivalry and competition between sisters - and that includes feminists. The vampiric collective of sisters emerges as a serious threat to the female individual.

The last Gothic book I analyzed is a novella by Vonne van der Meer, Spookliefde (Ghostly Love, 1995). This is the story of a young girl on a remote Irish island, seeking her first sexual experience with a man who turns out to have a twin brother. In this text the Gothic serves to represent issues of (female) sexual desire as causing friction between tradition and modernization. The recognition of female sexual autonomy is a relatively recent phenomenon. This novel deals, via the Gothic, with the friction between determinacy and surrender: how do the two relate? Desire may be dangerous, and cannot be pursued without loss. The many Gothic repetitions and duplications in the novel form a counterweight to notions of linearity 
and progression, and show the ambiguity of modernization and the modern subject's doubts. Future generations of young women will be haunted by the fear of not becoming sexually active, of not finding romantic love. It is worth noting that amid the many repetitions, the non-repeatable-the first time, the loss of virginity-does not occur. The analysis of anachronism in Spookliefde shows the potential connections between historical context and modernization processes. The remote and archaic Irish island forms a meaningful Gothic setting for this story, in which the protagonist develops a Catholic sensitivity. Spookliefde thereby defies the idea that modernization leads to secularization.

My analysis of these six novels shows that the Gothic is alive and well in Dutch literature and is employed in a variety of ways. Looking at these novels from the angle of the Gothic as a cultural strategy it is clear that something connects these particular authors. A new link is established and this is relevant for the study of Dutch literature. However, reading Gothic also makes it possible to study Dutch literature in an international context. Dutch authors are usually studied in isolation or only compared to one another. But of course literature is no longer a national phenomenon. Reading Gothic offers new views on international influences, kinships, and traditions. Finally, reading Gothic is a plea for interpretation, or as Brewster (2000) claims: "reading Gothic makes you see things."

Most likely due to the absence of a Gothic strain in historical Dutch literature, Dutch criticism of the Gothic only took off in the 1990s. ${ }^{3}$ Now that the critical perspective of reading Gothic has been established, new readings have become possible. Suddenly variations on Frankenstein can be recognized in a book like The Angel Maker (2005) by Stefan Brijs, and the presence of Gothic mansions, as in Marcel Möring's In Babylon (1997), makes sense. Class distinctions, 
usually regarded as trivial in post-war Dutch society, turn out to be a significant source of Gothic conflict. In Rosenboom's Vriend van verdienste, the suggestion of class mobility in the mid-1960s is enough to spawn a burst of sado-masochistic violence intended to restore order. Multicultural progressivism is the target of Herman Franke's Wolfstonen (Wolf Tones, 2003). This novel describes the inevitable conflicts between a group of liberal middle class residents in a post-modern apartment block and the original population of the seedy neighbourhood surrounding the apartment. The apartment residents' attempt to shut out the ugly noise (wolf tones) from outside is doomed to fail. Increasingly violent incidents culminate in the house going up in flames (Buikema \& Wesseling 2011).

In terms of the cultural work that the Gothic does, I concluded that in all novels under discussion the Gothic is a way of staging ambivalences about the achievements of the 1960s. In this decade, the Netherlands made an uncommonly rapid and seemingly smooth transition-compared to other European countries-from a religious, collectivist, traditionalist society to a progressive, secular, tolerant, and pluralist one. My analysis focused on issues of gender and sexual emancipation, which include new ways of defining masculinity and femininity, sexual equality, sexual autonomy of women and gay emancipation. Writers such as Anna Blaman, Willem Frederik Hermans, Jan Wolkers, Jan Cremer, and Gerard Reve have been attributed a historical role as trailblazers in these transformations, especially with regard to sexual emancipation (Kennedy 1995, Brems 2006). Interestingly, in these accounts it is always Reve's earlier work that is mentioned, not his Gothic De vierde man. In the 1980s, authors such as Frans Kellendonk, Gerard Reve and Renate Dorrestein, whose personal lives were influenced by these transitions-Reve and Kellendonk being well known gay 
men, Dorrestein an outspoken feminist-questioned the self-image of the Netherlands as an icon of sexual liberalization, women's and gay emancipation and individualization.

The ambivalences about modernization operate on two levels in these novels. Firstly, the novels express ambivalence about the dominance of new power relations. They question how firmly rooted these new values are and whether the old values have really lost their significance. The female protagonists in Dorrestein's Noorderzon and Perpetuum mobile van de liefde have to ward off the Evil Eye and vampiric doubles in order to claim their independence. In Dorrestein's later novel Heart of Stone (1998), modern child rearing philosophies are put to a horrific test, resulting in a family killing (Buikema \& Wesseling 2007).

Another level of ambivalence expressed by the Gothic refers to the value of those new societal relations. The Gothic elements serve to question whether the new is actually better than the old. Kellendonk's Letter en Geest and Van der Meer's Spookliefde raise doubts about the advantages of, respectively, gay emancipation and secularization.

The two levels of ambivalence are sometimes inseparable: in Gerard Reve's De vierde man the dominance of the new, equal gender relations is tested through parody, but "old fashioned" masculinity is simultaneously reinstalled as the ideal. The gay protagonist is driven to the brink of paranoia by his own performance as a heterosexual.

In my analysis of the Gothic in these six novels, I identified two remarkable correspondences between them. Firstly, all novels relate in some way or another to Catholicism: from perverted priests in Kellendonk and Dorrestein's novels, to Catholic formulas and rituals in Rosenboom, Van der Meer and Reve. I wondered how to explain this (surprising) recurrence. In classic English Gothic novels, strong 
anti-Catholic sentiments help shape certain concepts of (Protestant) British national identity. However, in these twentieth-century Dutch Gothic novels, Catholicism has no such nation-building function. Instead, Catholicism - possibly preferred over Protestantism because of its slightly more theatrical and ritualistic character-appears to be a suitable vehicle to express a desire for fulfilment and salvation. Even though the Catholic rituals in these texts are performed as parodies or perversions (except in Spookliefde), the desire does not seem to be less genuine. In my view, these Gothic texts thus demonstrate that secularization is not the self-evident outcome of modernity.

A second, remarkable correspondence between the novels is that they all question their protagonists' ability to truly lead their own lives. I interpret the abundance of Gothic Doppelgänger and stand-ins in these six novels in light of the expectation that every individual achieves self-actualization and lives an authentic life. The philosopher Charles Taylor (1991) has called this ethics of authenticity a typically modern phenomenon. Modern individualism entails the freedom to "be who you are", an achievement that enables people to a certain extent to determine the course of their own of lives. But this individualism is not without obligations, according to Taylor. Authenticity, "being who you are", is not just an ideal but a task with a social dimension; our authentic identity has "a need for recognition", as Taylor calls it. Self-definition is not recognizable or significant per se; any self-definition takes place in a context, the presence of others, against a horizon of choices that are deemed significant.

Taylor does not elaborate on the consequences of changing horizons. Who you can be or become is context-specific. When meanings of gender and sexuality change, articulations of the self change as well. Manifesting oneself as "modern" entails choices that 
vary historically, i.e. since the 1960s these choices have changed considerably, especially regarding sexuality, an area which is considered crucial to identity.

In the six Dutch novels from the 1980s examined here, Gothic is a way of expressing the ambivalences inherent in the new, post1960s societal relations, when articulations of the self in terms of gender and sexuality were reformulated. These Gothic novels show the insecurity individuals feel regarding who they can be in times of historical change. All six protagonists feel the call to become modern individuals, but do not know how to respond to that appeal. What does it mean to be a man (Reve, Rosenboom), a bachelor (Kellendonk), a homosexual (Reve en Kellendonk), a woman (Van der Meer), a feminist (Dorrestein), a friend (Rosenboom)? In the new social order, the answer to these questions is anything but clear. At such moments of insecurity, the Gothic rears its head.

\section{Notes}

1. I would like to thank the two anonymous referees for their constructive criticism.

2. For an overview of research on the Gothic in different domains and media, see Spooner \& McEvoy (2007).

3. Insofar as literary scholars in The Netherlands and Flanders had written about the Gothic until then (Von der Thüsen 1997, Van Gorp 1998), they had not written about Dutch Gothic.

\section{References}

Andeweg, Agnes. "The Ghost in the Closet. Frans Kellendonk and the Gothic." In: I. van Elferen (ed.), Nostalgia or Perversion? Gothic Rewriting from the Eighteenth Century until the Present Day. Newcastle: Cambridge Scholars Publishing, 2007.138-152. 
. Griezelig gewoon. Gotieke verschijningen in Nederlandse romans 1980-1995. Amsterdam: Amsterdam University Press, 2011.

Armstrong, Nancy. How Novels Think. The Limits of Individualism from 1719-1900. New York: Columbia University Press, 2005.

Baldick, Chris and Robert Mighall. "Gothic Criticism." In: David Punter (ed.), A Companion to the Gothic. Oxford: Blackwell Publishers, 2005. 209-229.

Beer, E.S. de. "Gothic: Origin and Diffusion of the Term; The Idea of Style in Architecture." Journal of the Warburg and Courtauld Institutes, Vol. 11, 1948. 143-162.

Bervoets, Jan. Nederlandse gruwelverhalen uit de negentiende eeuw. Utrecht: Veen (Dutch horror stories from the 19th century), 1983.

Botting, Fred. Gothic. The New Critical Idiom. New York, London: Routledge [1996], 2001.

Brems, Hugo. "Alles Moet Anders: Vier Polemieken Rond 1980." Altijd weer vogels die nesten beginnen. Geschiedenis van de Nederlandse literatuur 1945-2005. Amsterdam: Bert Bakker, 2006. 372-397.

Brewster, Scott. "Seeing Things: Gothic and the Madness of Interpretation." Ed. David Punter, A Companion to the Gothic. Oxford: Blackwell Publishers, 2000. 281-292.

Brooks, Peter. Reading for the Plot: Design and Intention in Narrative. Cambridge, MA \& London: Harvard University Press [1984], 1992.

Buikema, Rosemarie \& Elisabeth Wesseling. "Contesting Consensus Culture: the Case of Dutch Gothic." In: Journal for European Studies 41 (June 2011), 123-141.

. "Gothic Engineerings in Childrearing Manuals and Feminist Novels: Benjamin Spock Meets Renate Dorrestein." In: Isabella van Elferen (ed.), Nostalgia or Perversion? Gothic Rewriting from the Eighteenth Century until the Present Day. Newcastle: Cambridge Scholars Publishing, 2007. 152-167.

. Het Heilige Huis. De gotieke vertelling in de Nederlandse literatuur. Amsterdam: Amsterdam University Press [The Sacred Home: the Gothic Narrative in Dutch Literature], 2006. 
Butler, Judith. Gender Trouble. Feminism and the Subversion of Identity. New York, London: Routledge, 10th ed. [1990], 1999.

Clery, E.J. and R. Miles, eds. Gothic Documents. A Sourcebook 1700-1820. Manchester: Manchester University Press, 2000.

Dorrestein, Renate. Heart of Stone. Penguin Books. Original title: Een hart van steen. Amsterdam: Contact, 2002.

. Het perpetuum mobile van de liefde. Amsterdam: Contact [1988], 2002.

. Noorderzon. Amsterdam: Contact [1986], 1997.

Foucault, Michel. The History of Sexuality. New York: Pantheon [1976], 1978.

Gorp, Hendrik van. "Problems of comparative reception studies: The case of the Gothic Novel (1790-1825)", Journal of Literary Studies, Vol. 11, No. 3/4 (Dec.) 1995. 100-111.

Gorp, Hendrik van (1998). De romantische griezelroman (gothic novel): een merkwaardig randverschijnsel in de literatuur. Leuven: Garant, 1998.

Haasse, Hella. “De gothic novels van Renate Dorrestein,” in: Lezen achter de letters. Amsterdam: Querido, 283-295. Originally in Bzzlletin 166-167 (May-June 1989), 2000. 36-42.

Hanou, A. "Subliem? Romantisch?" [Review of Het verlangen naar huivering: over het sublieme, het wrede en het unheimliche: essays / Joachim von der Thüsen]. Tijdschrift voor Nederlandse Taal- en Letterkunde. Vol. 115, 1999. 356-364.

Kellendonk, Frans. Letter en Geest. Een spookverhaal. Amsterdam: Meulenhoff [1982], 1992.

Kennedy, James. Nieuw Babylon in aanbouw: Nederland in de jaren zestig. Amsterdam: Boom, 1995.

Kloek, J.J. and W.W. Mijnhardt. 1800. Blauwdrukken voor een samenleving. Den Haag: SDU, 2001.

Meer, Vonne van der. "Spookliefde." Een warme rug. Zo is hij. Spookliefde. Amsterdam: Contact, 211-287. [1995], 2002. 
Meer, Vonne van der. Inselliebe (German translation). Aufbau Taschenbuch. Original title: Spookliefde. Amsterdam: De Bezige Bij, 2010.

Mighall, Robert. A Geography of Victorian Gothic Fiction. Mapping History's Nightmares. Oxford UP, 1999.

Reve, Gerard. De vierde man. Antwerpen/Amsterdam: Elsevier Manteau (The Fourth Man), 1981.

Rosenboom, Thomas. Vriend van verdienste. Amsterdam: Querido (Friend of Merit), 1985.

Sedgwick, Eve Kosofsky. Between Men. English Literature and Male Homosocial Desire. New York: Columbia University Press, 1985.

Sinfield, Alan. Faultines: Cultural Materialism and the Politics of Dissident Reading, 1992.

Spooner, Catherine, \& Emma McEvoy, eds. The Routledge Companion to Gothic. London: Routledge, 2007.

Taylor, Charles. The Malaise of Modernity. Concord, Ontario: Anansi Press Ltd., 1991.

Thüsen, J.A. von der. Het verlangen naar huivering: over het sublieme, het wrede en het unheimliche. Amsterdam: Querido, 1997.

Tompkins, Jane. Sensational Designs. The Cultural Work of American Fiction 1790-1860. Oxford: Oxford University Press, 1985.

Zonneveld, Peter van. De ontslapen geliefde.. Amsterdam: Bert Bakker (The Deceased Lover; short stories), 1983.

Zuidinga, Robert-Henk. Boosaardig. Oorspronkelijke griezelverhalen. Amsterdam: Sijthoff. (Malicious. Original horror stories) www.nlpvf. nl Website of the Dutch Foundation for Literature, gives access to a database with translations of Dutch literature, 1986. Online.

. Uit den boze. Oorspronkelijke griezelverhalen. Amsterdam: Sijthoff. (Pernicious. Original horror stories), 1984.

[Received in 01/02/2012. Approved in 09/04/2012] 
